Research Article

\title{
Shear Strength Prediction Model of FRP Bar-Reinforced Concrete Beams without Stirrups
}

\author{
Danying Gao ${ }^{1,2}$ and Changhui Zhang $\mathbb{D}^{1,3}$ \\ ${ }^{1}$ School of Water Conservancy Engineering, Zhengzhou University, Zhengzhou, Henan 450001, China \\ ${ }^{2}$ Henan University of Engineering, Zhengzhou, Henan 451191, China \\ ${ }^{3}$ North China University of Water Resources and Electric Power, Zhengzhou, Henan 450046, China \\ Correspondence should be addressed to Changhui Zhang; changhuizhang@foxmail.com
}

Received 25 January 2020; Revised 29 February 2020; Accepted 10 March 2020; Published 9 April 2020

Academic Editor: A. M. Bastos Pereira

Copyright (C) 2020 Danying Gao and Changhui Zhang. This is an open access article distributed under the Creative Commons Attribution License, which permits unrestricted use, distribution, and reproduction in any medium, provided the original work is properly cited.

\begin{abstract}
The shear strength prediction model for fiber-reinforced polymer (FRP) bar-reinforced concrete beams without stirrups in ACI440.1R-2015 does not consider the "size effect" and the effect of shear span-to-depth ratio and predicts the zero-shear strength for concrete members without longitudinal reinforcement. A modified shear strength prediction model for FRP bar-reinforced concrete beams without stirrups was presented in this paper. The proposed model takes into account the effect of concrete strength, size of the beam, shear span-to-depth ratio, reinforcement ratio, and modulus of elasticity of the longitudinal reinforcement and the "size effect." The superiority of the proposed model has been evaluated by comparing the calculated shear strength of FRP bar-reinforced concrete beams without stirrups by the proposed model with the experimental results and calculated values by the models in design codes, respectively. It confirmed that the shear strength of FRP bar-reinforced concrete beams without stirrups by the proposed model was in better agreement with the experimental results.
\end{abstract}

\section{Introduction}

Fiber-reinforced polymer (FRP) bars have gained the acceptance as an alternative to conventional steel bars for concrete structures due to their corrosion resistance, high strength-to-weight ratio, and magnetic neutrality. It has been recognized that the flexural capacity of FRP barreinforced concrete beams can be predicted by the traditional assumptions used in steel bar-reinforced concrete beams. However, while FRP bars have two drawbacks including brittle failure and low modulus of elasticity compared with the steel bars, the shear behavior (including shear strength, deformation, and crack width) of concrete beams reinforced with the FRP bar is different from those reinforced with similar amount of steel reinforcement [1-4]. For example, the stiffness [3] and dowel action [4] of FRP barreinforced beams are smaller compared to the concrete beams with steel bars, subsequently resulting in the larger deformation and lower shear strength. Therefore, the existing shear strength prediction models for steel barreinforced beams cannot be directly applied to FRP barreinforced beams.

The shear strength prediction model of FRP bar-reinforced concrete beams in ACI440.1R-2015 [5] was based on the research by Tureyen and Frosch [6]. The ACI440.1R2015 model was a function of the width $(b)$ and effective depth $(d)$ of the beam, concrete compressive strength $\left(f_{c}^{\prime}\right)$, reinforcement ratio $\left(\rho_{f}\right)$, and modulus of elasticity $\left(E_{f}\right)$ of FRP bars, and the shear span-to-depth ratio $(a / d)$ was not included $[7,8]$. Several investigations confirmed that shear strength $V_{c}$ of FRP bar-reinforced concrete beams decreases as the a/d increases [7, 9-13]. Some investigators [7] revealed that $V_{c}$ decreases almost linearly with $(a / d)^{2 / 3}$, while the others [10] reported that it decreases linearly with $(a / d)^{1 / 3}$. In addition, the ACI440.1R-2015 model did not take into account the effect of concrete in the tensile zone of the beam on the shear strength for FRP bar-reinforced concrete beams without longitudinal reinforcement and 
predicted the zero-shear strength for concrete beams without longitudinal reinforcement [8]. Thirdly, the ACI440.1R-15 model did not take into account the "size effect" [14-17] which explains the phenomenon that the normalized shear strength of FRP bar-reinforced concrete beams decreases with the increasing of beam depth.

It has been recognized that $f_{c}^{\prime}, b, d, a / d, \rho_{f}$, and $E_{f}$ are the important parameters affecting the shear strength of FRP bar-reinforced concrete beams without stirrups. An equation that cannot predict the effects of known parameters would lack generality, and its applicability to general design situations would be uncertain [18]. Thus, there is a need to develop a modified shear strength prediction model for properly reflecting the effects of important parameters, which are known to affect the shear strength of FRP barreinforced beams without stirrups.

In this paper, a database of published test results on shear strength of 369 beams reinforced with FRP bars without stirrups was compiled. Considering the effects of $a / d$ on the shear strength of FRP bar-reinforced concrete beams without stirrups and the "size effect" and the contribution of the concrete to the shear strength for concrete beams without longitudinal reinforcement, a more accurate and rational-modified prediction model was proposed based on the ACI440.1R-2015 model. The efficiencies of the proposed model and ACI440.1R-2015, CAN/CSA-S806-2012 [19], JSCE-1997 [20], AASHTO LRFD-2017 [21], and CNRDT203-2006 [22] models were evaluated by comparing the calculated values with the experimental values in the database and the test data which are not contained in the database.

\section{Experimental Database}

To present a new shear strength prediction model of FRP bar-reinforced concrete beams without stirrups, a relatively large database including 369 beams reinforced with FRP bars without stirrups from 42 different investigations was established. The criteria for collecting the data of beam specimens were as follows: (1) rectangular cross sections; (2) simply supported; (3) tested under one- or two-point loading; (4) statically loaded; and (5) failed in shear. This database included various parameters which are known to affect the shear strength of FRP bar-reinforced concrete beams without stirrups, such as $a / d, f_{c}^{\prime}, b, d, \rho_{f}$, and $E_{f}$. The variation range of each parameter and the corresponding shear strength of the beam used in this study are given in Table 1, which is collected from the original source.

\section{Review of Shear Strength Prediction Models in Design Codes}

The shear strength prediction models of FRP bar-reinforced concrete beams without stirrups were highly valued by many countries, such as America, Japan, Canada, and Italy. The "size effect" and effects of $a / d, \rho_{f}$, and $E_{f}$ on the shear strength of FRP bar-reinforced concrete beams without stirrups were mainly considered in the shear strength prediction models of different design codes.
3.1. ACI440.1R-2015 Guidelines [5]. The shear strength calculating model of FRP bar-reinforced concrete beams without stirrups recommended by ACI Committee 440 is as follows:

$$
V_{c}^{\mathrm{aci}}=\frac{2}{5} \sqrt{f_{c}^{\prime}} b(k d),
$$

where $k=\sqrt{2 \rho_{f} n_{f}+\left(\rho_{f} n_{f}\right)^{2}}-\rho_{f} n_{f}, n_{f}=E_{f} / E_{c}$.

It can be clearly seen that equation (1) of the ACI440.1R2015 model predicts zero-shear strength for concrete beams without longitudinal reinforcement and does not consider the effect of $a / d$ on the shear strength of FRP bar-reinforced concrete beams without stirrups and the "size effect."

3.2. JSCE-1997 Design Recommendations [20]. The shear strength calculating model of FRP bar-reinforced concrete beams without stirrups recommended by Japan Society of Civil Engineering (JSCE-1997) is as follows:

$$
V_{c}^{\mathrm{jsce}}=\beta_{d} \beta_{\rho} \beta_{n} f_{v c d} b d,
$$

where $\beta_{d}=(1000 / d)^{1 / 4} \leq 1.5, \beta_{\rho}=\left(100 \rho E_{f} / E_{s}\right)^{1 / 3} \leq 1.5$, and $f_{v c d}=0.2 \sqrt[3]{f_{c}^{\prime}} \leq 0.72 \mathrm{MPa}$

It is the same as equation (1) of the ACI440.1R-15 model that equation (2) of the JSCE-1997 model predicts zeroshear strength for concrete beams without longitudinal reinforcement and does not consider the effect of $a / d$ on the shear strength of FRP bar-reinforced concrete beams without stirrups although it takes into account the "size effect" through $\beta_{d}$.

3.3. CAN/CSA-S806-2012 Design Provisions [19]. The shear strength calculating model of FRP bar-reinforced concrete beams without stirrups recommended by the Technical Committee on Design and Construction of Building Structures with Fibre-Reinforced Polymers of Canadian Standards Association (CAN/CSA-S806) is as follows:

$$
\begin{array}{r}
V_{c}^{s 806}=0.05 k_{m} k_{r} k_{a} k_{s} \sqrt[3]{f_{c}^{\prime}} b d, \\
0.11 \sqrt{f_{c}^{\prime}} b d \leq V_{c}^{s 806} \leq 0.22 \sqrt{f_{c}^{\prime}} b d,
\end{array}
$$

where $\quad k_{m}=\sqrt{d / a} \leq 1.0, \quad k_{r}=1+\sqrt[3]{E_{f} \rho_{f}}, \quad 1.0 \leq k_{a}=$ $2.5 d / a \leq 2.5$, and $k_{s}=750 /(450+d) \leq 1.0$.

Equation (3) of the CAN/CSA-S806-2012 model considers the effects of nearly all parameters on the shear strength of FRP bar-reinforced concrete beams without stirrups.

3.4. AASHTO LRFD-2017 Design Guide Specifications [21]. The shear strength calculating model of FRP bar-reinforced concrete beams without stirrups recommended by the American Association of State Highway and Transportation Officials is as follows: 
TABLE 1: Specimen details.

\begin{tabular}{|c|c|c|c|c|c|c|c|c|}
\hline Investigator & No. of specimens & $a / d$ & $f_{c}^{\prime}(\mathrm{MPa})$ & $b(\mathrm{~mm})$ & $d(\mathrm{~mm})$ & $E_{f}(\mathrm{GPa})$ & $\rho_{f}(\%)$ & $V_{c}(\mathrm{kN})$ \\
\hline Ashour and Kara $[15,23]$ & 18 & $2.5 \sim 5.9$ & $23 \sim 50.2$ & $150 \sim 200$ & $163 \sim 371$ & $32 \sim 142$ & $0.12 \sim 1.39$ & $9 \sim 36.1$ \\
\hline Gross $[4,24,25]$ & 42 & $4.1 \sim 6.5$ & $36.3 \sim 81.4$ & $65 \sim 279$ & $141 \sim 225$ & $41 \sim 139$ & $0.33 \sim 2.56$ & $8.8 \sim 51$ \\
\hline El-Sayedand El-Salakawy [26-28] & 18 & $3.1 \sim 6.5$ & $40 \sim 63$ & $250 \sim 1000$ & $155 \sim 326$ & $39 \sim 135$ & $0.39 \sim 2.63$ & $60 \sim 190$ \\
\hline Razaqpur et al. [10] & 7 & $1.8 \sim 4.2$ & $40.5 \sim 49$ & 200 & 225 & 145 & $0.25 \sim 0.88$ & $36.1 \sim 96.2$ \\
\hline Benmokrane [29] & 12 & $2.8 \sim 3.7$ & $34.1 \sim 43.2$ & $130 \sim 160$ & $310 \sim 346$ & $42 \sim 120$ & $0.72 \sim 1.54$ & $42.7 \sim 63.7$ \\
\hline Tureyen and Frosch [30] & 6 & 3.4 & $39.7 \sim 42.6$ & 457 & 360 & $38 \sim 47$ & $0.96 \sim 1.92$ & $94.7 \sim 177$ \\
\hline Nanni [31] & 3 & $2.6 \sim 2.7$ & 24.1 & 178 & $279 \sim 287$ & 40 & $0.77 \sim 2.3$ & $36.1 \sim 53.4$ \\
\hline Deitz and Harik [32] & 5 & $4.5 \sim 5.8$ & $27 \sim 30.8$ & 305 & 158 & 40 & 0.73 & $26.8 \sim 29.2$ \\
\hline Mizukawa [33] & 1 & 2.7 & 34.7 & 200 & 260 & 130 & 1.3 & 62.2 \\
\hline Duranovic [34] & 3 & 3.7 & $32.9 \sim 38.1$ & 150 & 210 & $45 \sim 130$ & $1.31 \sim 1.36$ & $26.2 \sim 62.2$ \\
\hline Swamy [35] & 2 & $3.2 \sim 4.1$ & $38 \sim 39$ & $154 \sim 305$ & $192 \sim 222$ & $34 \sim 42$ & $0.36 \sim 1.55$ & $19.5 \sim 26.7$ \\
\hline Suzuki [36] & 3 & 3 & 34.3 & 150 & 250 & 105 & $1.51 \sim 3.02$ & $40.5 \sim 46$ \\
\hline Alam and Hussein $[7,17]$ & 37 & $1.5 \sim 3.5$ & $34.5 \sim 88.3$ & $250 \sim 300$ & $291 \sim 744$ & $47 \sim 144$ & $0.18 \sim 1.47$ & $43.7 \sim 155.8$ \\
\hline Nakamura and Higai [37] & 2 & 3 & $22.7 \sim 27.8$ & 300 & 150 & 29 & $1.3 \sim 1.8$ & $33 \sim 36$ \\
\hline Bentz et al. [14] & 6 & $3.3 \sim 4.1$ & $35 \sim 46$ & 450 & $188 \sim 937$ & 37 & $0.51 \sim 2.54$ & $54.5 \sim 232$ \\
\hline Bažant and Yu [38] & 1 & 3.1 & 40 & 450 & 970 & 40 & 0.46 & 136 \\
\hline Wakui and Tottori [39] & 4 & 3.2 & $44.6 \sim 46.9$ & 200 & 325 & $58 \sim 192$ & $0.7 \sim 0.9$ & $87 \sim 118$ \\
\hline Nagasaka and Fukuyama [40] & 2 & 3.1 & $22.9 \sim 34.1$ & & 265 & 56 & 1.9 & \\
\hline Issa et al. [41] & 6 & $5.7 \sim 7$ & 35.9 & 300 & $165 \sim 170$ & $48 \sim 53$ & $0.8 \sim 4.12$ & $29.3 \sim 51.5$ \\
\hline Tomlinson and Fam [42] & 3 & $4.1 \sim 4.5$ & $56.5 \sim 60$ & 150 & $245 \sim 270$ & 70 & $0.39 \sim 0.85$ & $20.9 \sim 29.2$ \\
\hline Abed et al. [3] & 9 & $1 \sim 1.5$ & $43 \sim 65$ & 200 & $230 \sim 330$ & 51 & $0.92 \sim 1.84$ & $116.6 \sim 373.9$ \\
\hline ai et al. [43] & 3 & $1.1 \sim 3.3$ & $42.8 \sim 47.7$ & 150 & 223 & 45 & 1.28 & $27.2 \sim 81$ \\
\hline Kim and Jang[44] & 40 & $1.5 \sim 4.5$ & $30 \sim 40.3$ & $150 \sim 200$ & $214 \sim 216$ & $40 \sim 148$ & $0.33 \sim 0.79$ & $16.6 \sim 85.1$ \\
\hline Olivito and Zuccarello [45] & 20 & 5.6 & $20.4 \sim 27.2$ & 150 & 180 & 115 & $0.87 \sim 1.45$ & $16.6 \sim 29.9$ \\
\hline Matta et al. [46] & 12 & 3.1 & $29.5 \sim 59.7$ & $114 \sim 457$ & $146 \sim 883$ & $41 \sim 49$ & $0.12 \sim 0.28$ & $17.9 \sim 220.7$ \\
\hline Thomas and Ramadass [9] & 8 & $0.5 \sim 1.8$ & $40.6 \sim 65.3$ & $100 \sim 170$ & $270 \sim 416$ & 40 & $1.16 \sim 1.75$ & $30 \sim 300$ \\
\hline Wegian and Abdalla [47] & 6 & $6.5 \sim 9.5$ & 32.5 & 1000 & $105 \sim 155$ & $42 \sim 147$ & $0.23 \sim 0.96$ & $23.5 \sim 127$ \\
\hline Andermatt and Lubell [11] & 12 & $1.1 \sim 2.1$ & $39.9 \sim 68.5$ & $300 \sim 310$ & $257 \sim 891$ & $38 \sim 43$ & $1.47 \sim 2.13$ & $96 \sim 1134.5$ \\
\hline Huaxin and Genjin [13] & 13 & $1.1 \sim 2$ & $34.9 \sim 54.6$ & 200 & $260 \sim 360$ & $52 \sim 210$ & $0.76 \sim 1.16$ & $83.8 \sim 309.7$ \\
\hline Xiaoliang and Wenjun [48] & 3 & $2.5 \sim 2.7$ & $47.3 \sim 50.4$ & 300 & $300 \sim 315$ & 45 & $2.14 \sim 5.62$ & $85.3 \sim 122.7$ \\
\hline El Refai and Abed [8] & 8 & $2.5 \sim 3.3$ & 49 & 152 & $195 \sim 215$ & 50 & $0.31 \sim 1.53$ & $16.9 \sim 31.6$ \\
\hline Chang and Seo [49] & 14 & $5.8 \sim 8$ & 30 & 1200 & $130 \sim 182$ & $44 \sim 50$ & $0.24 \sim 1.22$ & $26.3 \sim 159$ \\
\hline Abdul-Salam et al. [50] & 16 & $5.7 \sim 6.3$ & $41.3 \sim 86.2$ & 1000 & $134 \sim 150$ & $41 \sim 148$ & $0.51 \sim 3.78$ & $94 \sim 213$ \\
\hline Farghaly and Benmokrane [51] & 4 & 1.1 & $38.7 \sim 49.3$ & 300 & $1088 \sim 1111$ & $48 \sim 144$ & $0.26 \sim 1.24$ & $595.5 \sim 953$ \\
\hline Ali et al. [12] & 12 & $2.3 \sim 3$ & $13 \sim 33.5$ & 130 & $196 \sim 200$ & 52 & $0.3 \sim 0.91$ & $12.7 \sim 39.4$ \\
\hline Omeman et al. [1] & 8 & $1.4 \sim 2.3$ & $34.7 \sim 63.1$ & 150 & $387 \sim 662$ & 134 & $1.13 \sim 2.26$ & $45.8 \sim 234.1$ \\
\hline Total & 369 & $0.5 \sim 9.5$ & $13 \sim 88.3$ & $65 \sim 1200$ & $105 \sim 1111$ & 29 210 & $0.12 \sim 5.62$ & $8.8 \sim 1134.5$ \\
\hline
\end{tabular}

Note: if the concrete cylinder compressive strength $f_{c}^{\prime}$ and modulus of elasticity of concrete $E_{c}$ were not provided by the investigator while the concrete cube compressive strength $f_{c u}$ was only measured, it is assumed that $f_{c}^{\prime}=0.8 f_{c u}$ and $E_{c}=4733 \sqrt{f_{c}^{\prime}}$. If the unit of data was BS provided by the investigator, it is converted by the following factors: $1 \mathrm{ksi}=6.895 \mathrm{MPa}, 1 \mathrm{in}=25.4 \mathrm{~mm}$, and $1 \mathrm{kip}=4.448 \mathrm{KN}$.

$$
V_{c}^{\mathrm{Irfd}}=\left(0.0676 \sqrt{f_{c}^{\prime}}+4.6 \rho_{f} \frac{d}{a}\right) b d \leq 0.126 \sqrt{f_{c}^{\prime}} b d .
$$

Equation (5) of the AASHTO LRFD-2017 model considers the effects of $a / d$ and $\rho_{f}$ on the shear strength of FRP bar-reinforced concrete beams without stirrups while the effect of $E_{f}$ and the "size effect" are not included.

3.5. CNR-DT203-2006 [22]. The shear strength of FRP barreinforced concrete beams without stirrups recommended by Advisory Committee Technical Recommendations Construction of Italian National Research Council is as follows:

$$
V_{c}^{\mathrm{cnr}}=1.3\left(E_{f} / E_{s}\right)^{1 / 2} \tau_{r} k_{d}\left(1.2+40 \rho_{f}\right) b d
$$

where $1.3\left(E_{f} / E_{s}\right)^{1 / 2} \leq 1, \tau_{r}=0.25 f_{t}, k_{d}=1.6-(d / 1000) \geq$ 1 , and $\rho_{f} \leq 0.02$.
Equation (6) of the CNR-DT203-2006 model considers the "size effect" through $k_{d}$ and does not consider the effect of a/d on the shear strength of FRP bar-reinforced concrete beams without stirrups.

\section{Proposed Shear Strength Prediction Model}

According to the experimental database mentioned above, the normalized shear strength $V_{c}^{\mathrm{exp}} / \sqrt{f_{c}^{\prime}} b d$ was plotted against $\rho_{f} n_{f}\left(n_{f}=E_{f} / E_{c}\right)$ as shown in Figure 1(a). It can be seen that the relationship between the normalized shear strength $V_{c}^{\exp } / \sqrt{f_{c}^{\prime}} b d$ and $\rho_{f} n_{f}$ fits into the trendline in Figure 1(a) except some plots. To express this trendline with a reasonable equation, the normalized shear strength $V_{c}^{\exp } / \sqrt{f_{c}^{\prime}} b d$ was also plotted against $k \quad(k=$ 


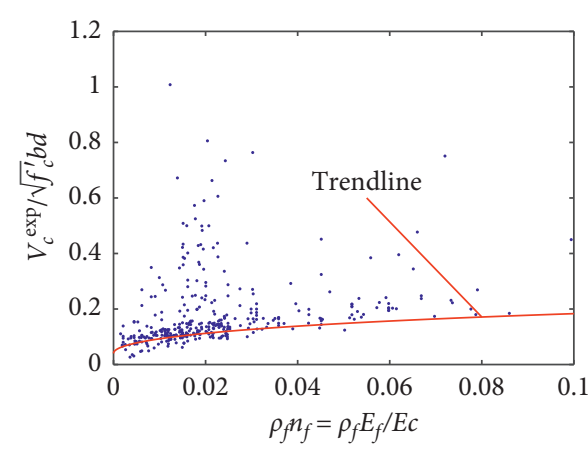

(a)

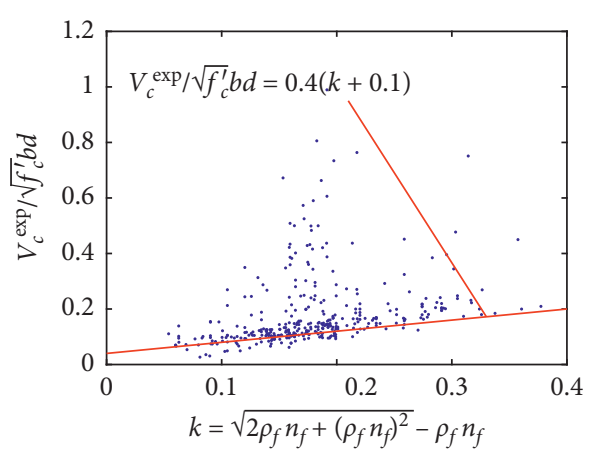

(b)

Figure 1: Effect of $\rho_{f} n_{f}$ and $k$ on $V_{c}^{\exp } / \sqrt{f_{c}^{\prime}} b d$.

$\left.\sqrt{2 \rho_{f} n_{f}+\left(\rho_{f} n_{f}\right)^{2}}-\rho_{f} n_{f}\right)$ as shown in Figure 1(b), where $k$ can be defined as the relative depth of the compressive zone because the depth of compressive zone $c$ can be calculated by multiplying $d$ by $k(c=k d)$. From the regression of the results of FRP bar-reinforced concrete beams without stirrups, there is a linear equation between $V_{c}^{\exp } / \sqrt{f_{c}^{\prime}} b d$ and $k$, which can be written as

$$
\frac{V_{c}^{\text {exp }}}{\sqrt{f_{c}^{\prime} b d}}=0.4(k+0.1) .
$$

Equation (7) can take into account the effects of $\rho_{f}$ and $E_{f}$ on the shear strength for FRP bar-reinforced concrete beams without stirrups and the contribution of concrete on shear strength for FRP bar-reinforced concrete beams without longitudinal reinforcement.

4.1. Effect of Shear Span-to-Depth Ratio $(a / d)$ on the Shear Strength. In order to eliminate the influence of $\rho_{f}$ and $E_{f}$ on shear strength of FRP bar-reinforced concrete beams without stirrups, the normalized shear strength was taken as $V_{c}^{\exp } / 0.4 \sqrt{f_{c}^{\prime}} b(k+0.1) d$ on the basis of equation (7), which was plotted against $a / d$ according to the experimental database mentioned above, as shown in Figure 2. Evidently, $V_{c}^{\exp } / 0.4 \sqrt{f_{c}^{\prime}} b(k+0.1) d$ decreases as a/d increases, and there is a trendline between $V_{c}^{\exp } / 0.4 \sqrt{f_{c}^{\prime}} b(k+0.1) d$ with $a / d$. The relationships between $V_{c}^{\exp } / 0.4 \sqrt{f_{c}^{\prime}} b(k+0.1) d$ and $a / d$ can be obtained by the regressions based on the following three criteria:

(1) The regressions can be described in four forms depending upon the value of $a / d$ or determined by the types of failure referred to those for steel barreinforced beams [52].

Diagonal compression failure (when $0 \leq a / d<1$ ):

$$
\frac{V_{c}^{\exp }}{0.4 \sqrt{f_{c}^{\prime}} b(k+0.1) d}=f_{1}(a / d) .
$$

Shear compression failure (when $1 \leq a / d<3$ ):

$$
\frac{V_{c}^{\exp }}{0.4 \sqrt{f_{c}^{\prime}} b(k+0.1) d}=f_{2}\left(\frac{a}{d}\right) .
$$

Diagonal tension failure (when $3 \leq a / d<6$ ):

$$
\frac{V_{c}^{\exp }}{0.4 \sqrt{f_{c}^{\prime}} b(k+0.1) d}=f_{3}\left(\frac{a}{d}\right) .
$$

Bending failure (when $a / d \geq 6$ ):

$$
\frac{V_{c}^{\exp }}{0.4 \sqrt{f_{c}^{\prime}} b(k+0.1) d}=f_{4}\left(\frac{a}{d}\right) .
$$

(2) The regressions remain coordinated on boundary conditions

$$
\begin{aligned}
& f_{1}(1)=f_{2}(1) \\
& f_{2}(3)=f_{3}(3), \\
& f_{3}(6)=f_{4}(6) .
\end{aligned}
$$

(3) According to Reinforced Concrete Design to Eurocode 2 [53], when $\rho_{f}=0$ and $a / d=0$, the shear strength can be calculated by the following equation:

$$
V_{c}^{\rho_{f}=0, a / d=0}=\tau b d .
$$

The shear strength of concrete $\tau$ can be expressed by the tension strength of concrete $f_{t}$ as follows [52]:

$$
\tau=\alpha f_{t},
$$

where $\alpha$ is a constant, generally, $\alpha=1.5-2.5$. Conservatively, here, $\alpha=1.6$.

The concrete tension strength $f_{t}$ can be evaluated with the equation in ACI318-14 [54] as follows:

$$
f_{t}=\frac{5}{8} \sqrt{f_{c}^{\prime}} .
$$




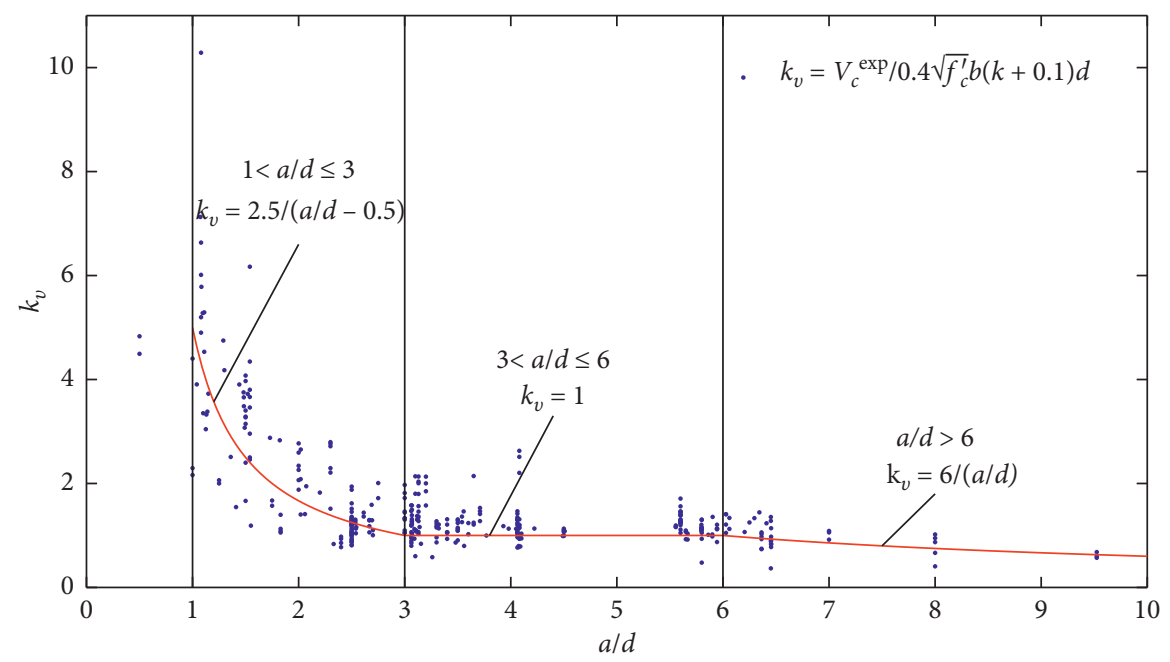

Figure 2: Effect of $a / d$ on $V_{c}^{\exp } / 0.4 \sqrt{f_{c}^{\prime}} b(k+0.1) d$.

Substituting the values of $f_{t}$ in equation (15) into equation (14), the equation for shear strength of concrete can be rewritten as

$$
\tau=\sqrt{f_{c}^{\prime}}
$$

Substituting the values of $\tau$ in equation (16) into equation (13), when $\rho_{f}=0$ and $a / d=0$, the equation for the shear strength of the FRP bar-reinforced concrete beams without stirrups can be rewritten as

$$
V_{c}^{\rho_{f}=0, a / d=0}=\sqrt{f_{c}^{\prime}} b d .
$$

Based on the regressions of the database aforementioned, as shown in Figure 2, the functions between $V_{c}^{\exp } / 0.4 \sqrt{f_{c}^{\prime}} b(k+0.1) d$ and $a / d$ can be obtained as follows:

$$
\begin{aligned}
& f_{2}\left(\frac{a}{d}\right)=\frac{2.5}{(a / d)-0.5} \\
& f_{3}\left(\frac{a}{d}\right)=1, \\
& f_{4}\left(\frac{a}{d}\right)=\frac{6}{a / d} .
\end{aligned}
$$

As there are only two specimens in the database whose shear span-to-depth ratio is below 1.0, no more data can be employed for regression; therefore, the function of $f_{1}(a / d)$ could be set up according to the criterions (2) and (3) as follows:

$$
f_{1}\left(\frac{a}{d}\right)=\frac{(1-(a / d)) /(1+(a / d))}{0.4(k+0.1)}+5\left(\frac{a}{d}\right) .
$$

Then, the equation for shear strength of FRP bar-reinforced concrete beams without stirrups, which considers the effect of shear span-to-depth ratio $(a / d)$, can be modified as follows:

$$
V_{c}=k_{f a d} \sqrt{f_{c}^{\prime}} b d,
$$

where

$$
k_{f a d}= \begin{cases}\frac{(1-(a / d))}{(1+(a / d))}+2(k+0.1)\left(\frac{a}{d}\right), & \text { while } \frac{a}{d} \leq 1, \\ \frac{(k+0.1)}{((a / d)-0.5)}, & 1<\frac{a}{d} \leq 3, \\ 0.4(k+0.1), & \text { while } 3<\frac{a}{d} \leq 6, \\ \frac{2.4(k+0.1)}{(a / d)}, & \text { while } a / d>6 .\end{cases}
$$

4.2. "Size Effect" on the Shear Strength. According to the experimental database mentioned above and equation (21), the normalized shear strength $V_{c}^{\mathrm{exp}} / k_{f a d} \sqrt{f_{c}^{\prime}} b d$ was plotted against $a / d, f_{c}^{\prime}, b, d, \rho_{f}$, and $E_{f}$ as shown in Figure 3, respectively. It can be seen that $V_{c}^{\exp } / k_{f a d} \sqrt{f_{c}^{\prime}} b d$ does not have the obvious variation with the increase of $b, d, f_{c}^{\prime}, \rho_{f}, E_{f}$, and $a / d$, respectively, but there is a relation between $V_{c}^{\exp } / k_{f a d} \sqrt{f_{c}^{\prime}} b d$ and $d$. It indicates that the influence of $b, d$, $f_{c}^{\prime}, \rho_{f}, E_{f}$, and a/d upon the shear strength of FRP barreinforced concrete beams without stirrups has been embodied reasonably well by equation (20) except the influence of $d$. This phenomenon demonstrates the "size effect" exists on the shear strength of FRP bar-reinforced concrete beams without stirrups mentioned in the literature review.

Then, referring to Eurocode 2 for the shear capacity of concrete reinforced with the steel bar, the equation for shear strength of FRP bar-reinforced concrete beams without stirrups, which has taken into account the "size effect" by a linear reduction form [15], can be established as follows:

$$
V_{c}=k_{f a d} k_{d} \sqrt{f_{c}^{\prime}} b d,
$$

where 


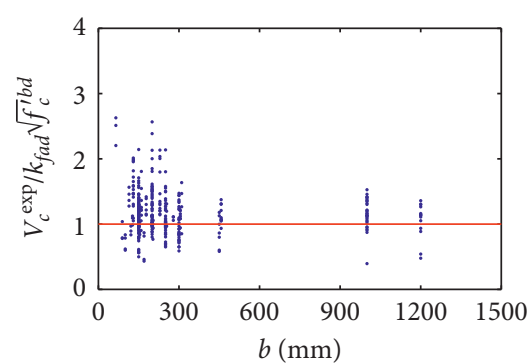

(a)

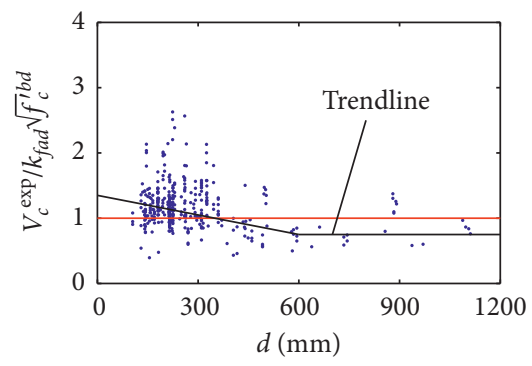

(d)

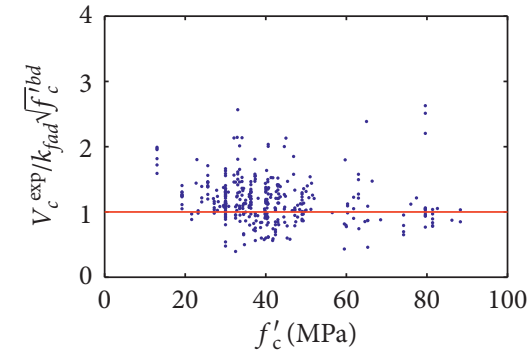

(b)

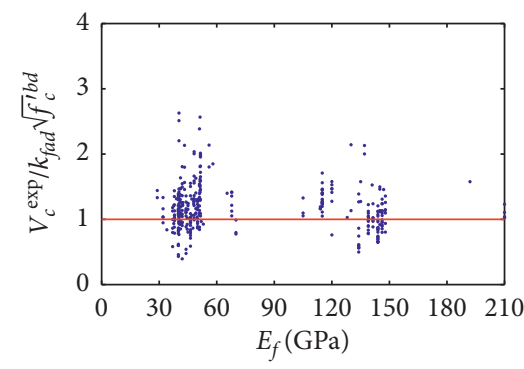

(e)

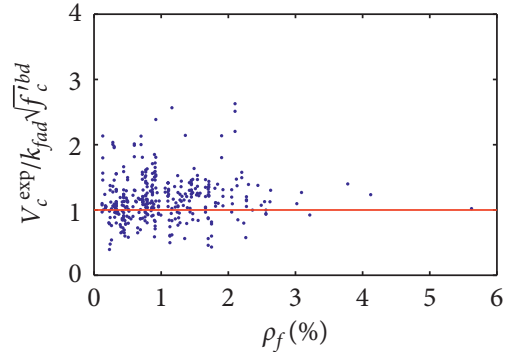

(c)

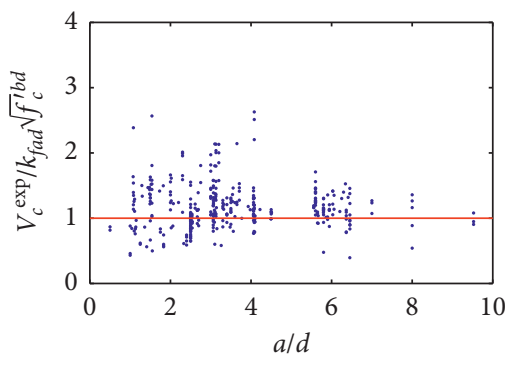

(f)

FiguRE 3: Effect of parameters on $V_{c}^{\exp } / k_{\text {fad }} \sqrt{f_{c}^{\prime}} b d$.

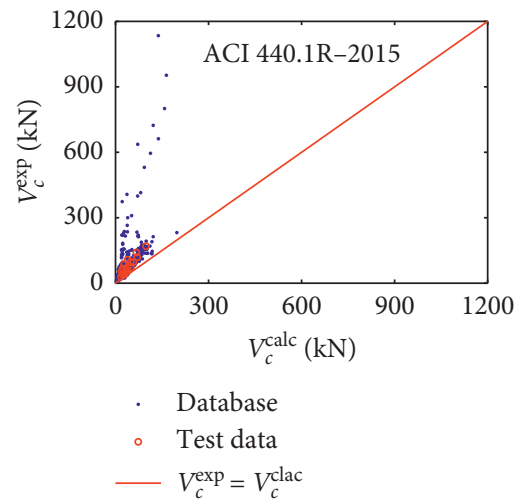

(a)

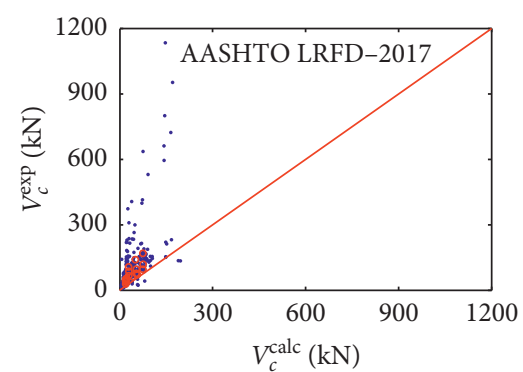

- Database

- Test data

$-V_{c}^{\exp }=V_{c}^{\text {clac }}$

(d)

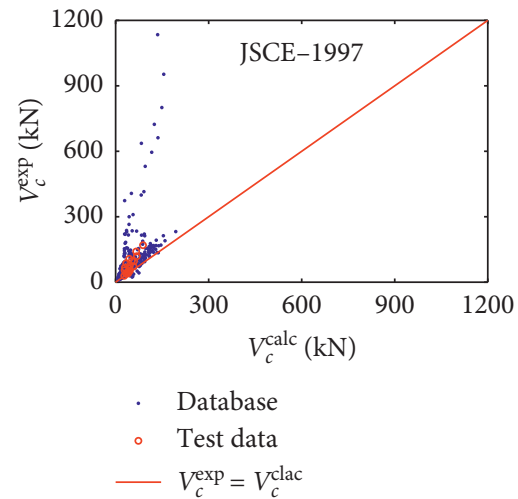

(b)

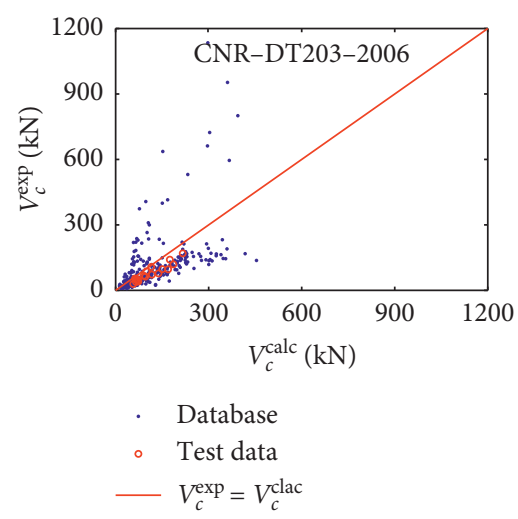

(e)

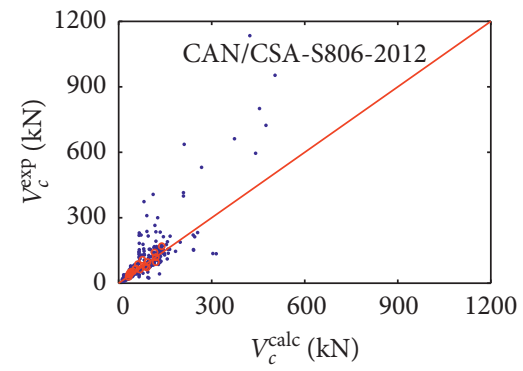

. Database

- Test data

$-V_{c}^{\text {exp }}=V_{c}^{\text {clac }}$

(c)

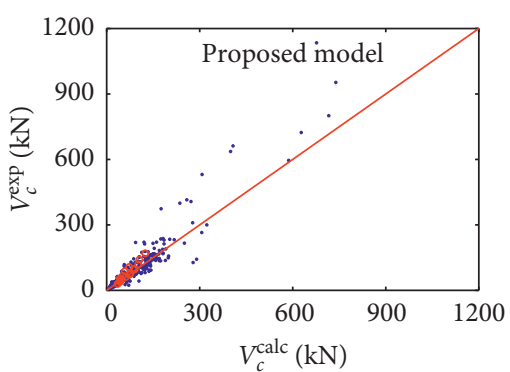

- Database

- Test data

$-V_{c}^{\exp }=V_{c}^{\text {clac }}$

(f)

Figure 4: Comparison of $V_{c}^{\text {exp }}$ and $V_{c}^{\text {calc }}$. 

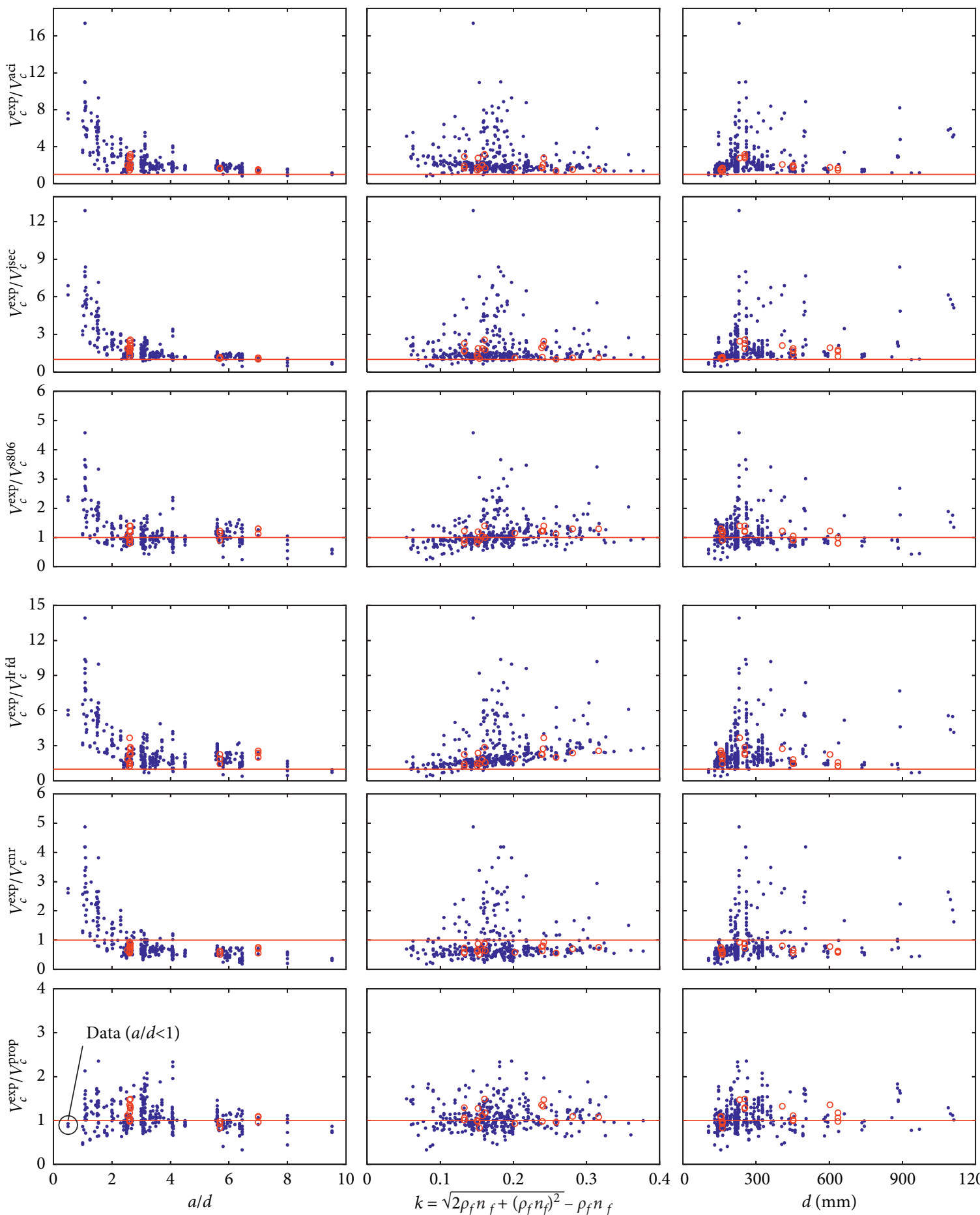

- Database

- Test data

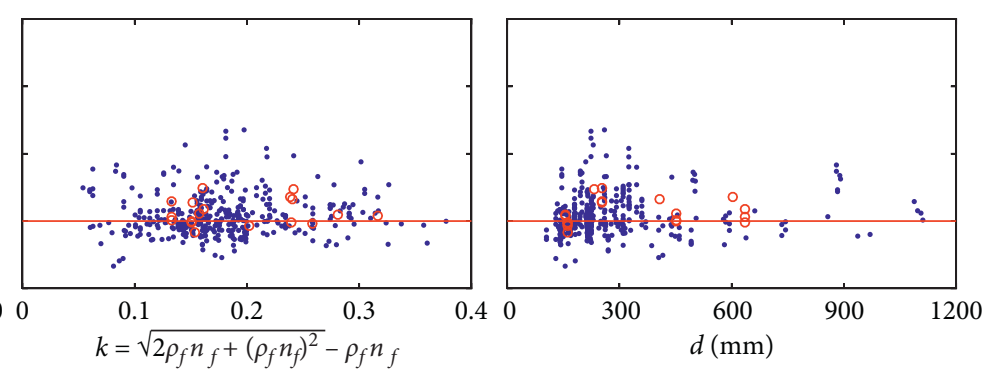

Figure 5: Influence of $a / d, k$, and $d$ on shear strength predictions. 


$$
k_{d}=1.35-\frac{d}{1000} \geq 0.75
$$

\section{Comparison of Predicted Shear Strength and Experimental Results}

Figure 4 presents the correlations of the experimental shear strength $V_{c}^{\text {exp }}$ of all 369 specimens in the database mentioned above and another 18 test data of specimens from Jumaa and Yousif [55] and Ovitigala [56] with the calculated shear strengths $V_{c}^{\text {aci }}, V_{c}^{\text {jsce }}, V_{c}^{s 806}, V_{c}^{\mathrm{lrfd}}, V_{c}^{\mathrm{cnr}}$, and $V_{c}^{\mathrm{prop}}$, respectively. A line with tolerance of $0 \%$ has been represented in the graph, which indicates that the exact prediction $V_{c}^{\exp } / V_{c}^{\text {calc }}=$ 1 of the shear strength. It can be seen that the ACI440.1R2015, JSCE-1997, and AASHTO LRFD-2017 models provide conservative predictions of the shear strengths of the most specimens $\left(V_{c}^{\exp } / V_{c}^{\text {calc }}>1\right)$; the predictions of the CNRDT203-2006 model are highly unconservative for many specimens; the CAN/CSA-S806-2012 model shows better agreement with the experiment results than other models in the design codes aforementioned; and the predictions of the proposed model by equation (22) fit better with the experiment results than all the models in the design codes aforementioned.

Figure 5 illustrates the relationships among the shear strength ratio of the experimental shear strength to the calculated shear strength $V_{c}^{\exp } / V_{c}^{\text {calc }}$ and $a / d, k$, and $d$, respectively. As shown in Figure 5 , the ratio of $V_{c}^{\exp } / V_{c}^{\text {calc }}$ decreases as $a / d$ increases, while $a / d \leq 2.5$ for all the models in the design codes aforementioned; both ratios of $V_{c}^{\exp } / V_{c}^{s 806}$ and $V_{c}^{\exp } / V_{c}^{\text {lrfd }}$ increase as $k$ increases, for the CAN/CSAS806-2012 model does not well consider the effects of $\rho_{f}$ nor $E_{f}$, and the AASHTO LRFD-2017 model does not consider the effect of $E_{f}$; and the ratio of $V_{c}^{\exp } / V_{c}^{\text {prop }}$ does not have obvious variation with the increase of $a / d, k$, or $d$. Moreover, the proposed model has the least scatter range of $V_{c}^{\exp } / V_{c}^{\text {prop }}$ from 0.39 to 2.63 , whilst the scatter range of $V_{c}^{\exp } / V_{c}^{\text {calc }}$ for ACI440.1R-2015, JSCE-1997, CAN/CSA-S806-2012, AASHTO LRFD-2017, and CNR-DT203-2006 models is from 0.82 to $17.38,0.44$ to $12.88,0.24$ to $4.58,0.39$ to 13.91 , and 0.18 to 4.87 , respectively. Hence, the effect of $a / d, \rho_{f}, E_{f}$, and $d$ on shear strength normalized by the proposed model of equation (22) is captured reasonably well. It should be mentioned that the predicted values by the proposed model for the two specimens with shear span-to-effective depth less than 1 are in good agreement with the experimental values $\left(V_{c}^{\exp } / V_{c}^{\text {prop }}=1\right)$ though the function of the proposed model $(a / d \leq 1)$ was not obtained by the regression method.

The ratios of $V_{c}^{\mathrm{exp}} / V_{c}^{\text {prop }}$ are presented graphically using a histogram as shown in Figure 6. The horizontal axis of the figure shows the ratio of $V_{c}^{\exp } / V_{c}^{\text {prop }}$, and the vertical axis represents the frequency of the specimens for a certain $V_{c}^{\exp } / V_{c}^{\text {prop }}$ ratio. It can be seen that the values of $V_{c}^{\exp } / V_{c}^{\text {prop }}$ follow a normal distribution, and $60 \%$ of the values is in a narrow range 0.8 to 1.2 .

To further investigate the superiority of the proposed shear strength prediction model of FRP bar-reinforced concrete beams without stirrups, a total of three

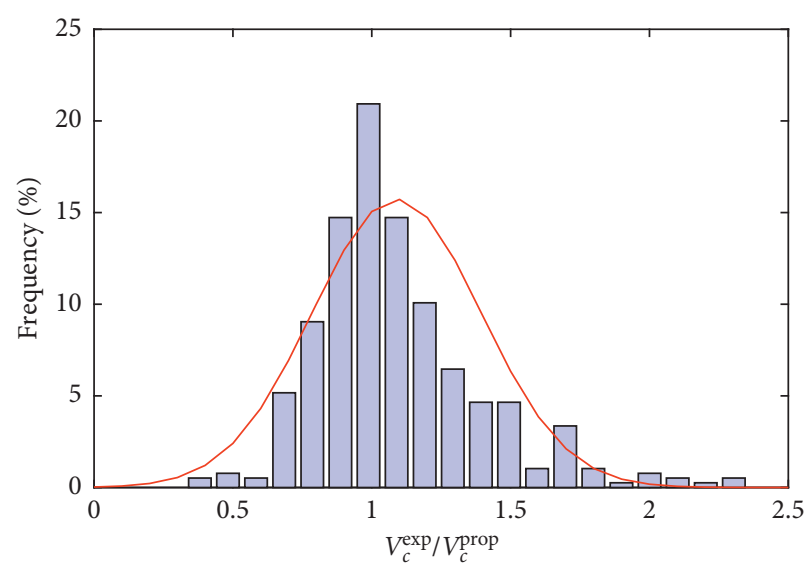

Figure 6: Histogram of the predictions of the proposed model.

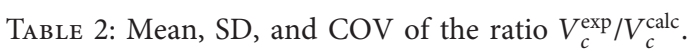

\begin{tabular}{lcccccc}
\hline \multirow{2}{*}{ Performance checks } & \multicolumn{3}{c}{ Regression database } & \multicolumn{3}{c}{ Test data } \\
& Mean & SD & COV & Mean & SD & COV \\
\hline$V_{c}^{\exp } / V_{c}^{\text {aci }}$ & 2.61 & 1.84 & 0.70 & 1.95 & 0.55 & 0.28 \\
$V_{c}^{\exp } / V_{c}^{\text {Irfd }}$ & 2.55 & 1.73 & 0.68 & 2.09 & 0.64 & 0.30 \\
$V_{c}^{\exp } / V_{c}^{\text {sce }}$ & 1.92 & 1.45 & 0.76 & 1.63 & 0.50 & 0.30 \\
$V_{c}^{\exp } / V_{c}^{s 806}$ & 1.15 & 0.52 & 0.45 & 1.12 & 0.19 & 0.17 \\
$V_{c}^{\exp } / V_{c}^{\text {cnr }}$ & 0.90 & 0.69 & 0.77 & 0.69 & 0.12 & 0.18 \\
$V_{c}^{\exp } / V_{c}^{\text {prop }}$ & 1.09 & 0.31 & 0.28 & 1.14 & 0.19 & 0.17 \\
\hline
\end{tabular}

performance checks were adopted. The mean, standard deviation (SD), and coefficient of variation (COV) of the ratio $V_{c}^{\exp } / V_{c}^{\text {calc }}$ are given in Table 2 . It can be observed that the proposed model, as a whole, predicts the shear strength of FRP bar-reinforced concrete beams without stirrups with smaller SD and COV values than ACI440.1R-2015, JSCE1997, AASHTO LRFD-2017, CNR-DT203-2006, and CAN/ CSA-S806-2012 models.

\section{Conclusions}

The impacts of shear span-to-depth ratio upon the shear strength of FRP bar-reinforced concrete beams without stirrups and the "size effect" were investigated by analyzing the collected experimental results. A new model for the shear strength prediction of FRP bar-reinforced concrete beams without stirrups was proposed by using the regression method based on the experimental database. The main conclusions of this research are summarized as follows:

(1) The proposed model considers the "size effect" and the effect of shear span-to-depth ratio on the shear strength for FRP bar-reinforced concrete beams without stirrups, which decrease as the shear spanto-depth ratio and effective depth increase, respectively.

(2) The values of experimental results for the shear strength of FRP bar-reinforced concrete beams without stirrups to calculated values by the proposed model follow a normal distribution, and $60 \%$ of the values distribute in a narrow range 0.8 to 1.2 . 
(3) The proposed model has more reasonable and reliable predictions for the shear strength of FRP barreinforced concrete beams without stirrups in comparison with the models in design codes mentioned.

\section{Notations}

$f_{c}^{\prime}$ : Cylinder compressive strength of concrete, $\mathrm{MPa}$

$f_{c u}$ : Cube compressive strength of concrete, $\mathrm{MPa}$

$f_{t}: \quad$ Tension strength of concrete, $\mathrm{MPa}$

a: $\quad$ Shear span, $\mathrm{mm}$

$b$ : $\quad$ Beam width, $\mathrm{mm}$

$d$ : $\quad$ Effective depth, $\mathrm{mm}$

a/d: Shear span-to-depth ratio

$k$ : $\quad$ Relative depth of the compressive zone

$c$ : $\quad$ Depth of the compressive zone, $\mathrm{mm}$

$\rho_{f}: \quad$ Reinforcement ratio

$n_{f}: \quad$ Modular ratio

$E_{f}$ : Modulus of elasticity of FRP bars, $\mathrm{MPa}$

$E_{c}$ : $\quad$ Modulus of elasticity of concrete, $\mathrm{MPa}$

$V_{c}$ : Shear strength of FRP bar-reinforced concrete beams, $\mathrm{N}$

$V_{c}^{\text {exp }}$ : Experimental shear strength, $\mathrm{N}$

$V_{c}^{\text {calc. }}$ Calculated shear strength, $\mathrm{N}$

$V_{c}^{\text {prop }}$ : Calculated shear strength using the proposed model, $\mathrm{N}$

$V_{c}^{\text {aci. }} \quad$ Calculated shear strength using the ACI440.1R-15 model, $\mathrm{N}$

$V_{c}^{\mathrm{jsce}}:$ Calculated shear strength using the JSCE-1997 model, N

$V_{c}^{s 806}$ : Calculated shear strength using the CAN/CSA-S8062012 model, N

$V_{c}^{\mathrm{lrfd}}$ : Calculated shear strength using the AASHTO LRFD2017 model, N

$V_{c}^{\mathrm{cnr}}$ : Calculated shear strength using the CNR-DT2032006 model, N.

\section{Data Availability}

All data included in this study are available upon request by contact with the corresponding author.

\section{Conflicts of Interest}

The authors declare that they have no conflicts of interest.

\section{Acknowledgments}

This research was financially supported by the National Natural Science Foundation of China (Grant no. U1704254).

\section{References}

[1] Z. Omeman, M. Nehdi, and H. El-Chabib, "Experimental study on shear behavior of carbon-fiber-reinforced polymer reinforced concrete short beams without web reinforcement," Canadian Journal of Civil Engineering, vol. 35, no. 1, pp. 1-10, 2008.
[2] M. Abed, Z. Omeman, and H. El-Chabib, "Optimal efficiency factor in strut-and-tie model for FRP-reinforced concrete short beams with $(1.5<a / d<2.5)$," Materials and Structures, vol. 41, no. 10, pp. 1713-1727, 2008.

[3] F. Abed, H. El-Chabib, and M. AlHamaydeh, "Shear characteristics of GFRP-reinforced concrete deep beams without web reinforcement," Journal of Reinforced Plastics and Composites, vol. 31, no. 16, pp. 1063-1073, 2012.

[4] J. R. Yost, S. P. Gross, and D. W. Dinehart, "Shear strength of normal strength concrete beams reinforced with deformed GFRP bars," Journal of Composites for Construction, vol. 5, no. 4, pp. 268-275, 2001.

[5] ACI Committee 440, Guide for the Design and Construction of Concrete Reinforced with Fiber Rienforced Polymers (FRP) Bars (ACI 440.1R-15), ACI Committee, Farmington Hills, MI, USA, 2015.

[6] A. K. Tureyen and R. J. Frosch, "Concrete shear strength: another perspective," ACI Structural Journal, vol. 100, no. 5, pp. 609-615, 2003.

[7] M. S. Alam and A. Hussein, "Unified shear design equation for concrete members reinforced with Fiber-Reinforced polymer without stirrups," Journal of Composites for Construction, vol. 17, no. 5, pp. 575-583, 2013.

[8] A. El Refai and F. Abed, "Concrete contribution to shear strength of beams reinforced with basalt Fiber-Reinforced bars," Journal of Composites for Construction, vol. 20, no. 4, pp. 1-13, 2016.

[9] J. Thomas and S. Ramadass, "Parametric study of shear strength of concrete beams reinforced with FRP bars," Journal of The Institution of Engineers (India): Series A, vol. 97, no. 3, pp. 273-284, 2016

[10] A. G. Razaqpur, B. O. Isgor, S. Greenaway, and A. Selley, "Concrete contribution to the shear resistance of fiber reinforced polymer reinforced concrete members," Journal of Composites for Construction, vol. 8, no. 5, pp. 452-460, 2004.

[11] M. F. Andermatt and A. S. Lubell, "Behavior of concrete deep beams reinforced with internal Fiber-Reinforced Polymer-Experimental study," ACI Structural Journal, vol. 110, no. 4, pp. 585-594, 2013.

[12] I. Ali, R. Thamrin, A. A .S. Abdul, and M. Noridah, "Diagonal shear cracks and size effect in concrete beams reinforced with glass fiber reinforced polymer (GFRP) bars," Applied Mechanics and Materials, vol. 621, pp. 113-119, 2014.

[13] L. Huaxin and L. Genjin, "Shear capacity of basalt fiber reinforced polymer reinforced recycled concrete deep beam without web reinforcement," Journal of Sichuan University (Engineering Science Edition), vol. 47, no. 5, pp. 17-22, 2015.

[14] E. C. Bentz, L. Massam, and M. P. Collins, "Shear strength of large concrete members with FRP reinforcement," Journal of Composites for Construction, vol. 14, no. 6, pp. 637-646, 2010.

[15] A. F. Ashour and I. F. Kara, "Size effect on shear strength of FRP reinforced concrete beams," Composites Part B: Engineering, vol. 60, pp. 612-620, 2014.

[16] M. S. Alam and A. Hussein, "Effect of member depth on shear strength of high-strength fiber-reinforced polymer-reinforced concrete beams," Journal of Composites for Construction, vol. 16, no. 2, pp. 119-126, 2012.

[17] M. S. Alam and A. Hussein, "Size effect on shear strength of FRP reinforced concrete beams without stirrups," Journal of Composites for Construction, vol. 17, no. 4, pp. 507-516, 2013.

[18] A. G. Razaqpur, "Proposed shear design method for FRPReinforced concrete members without stirrups," ACI Structural Journal, vol. 103, no. 1, 2006. 
[19] Canadian Standards Association, Design and Construction of Building Structures with Fibre-Reinforced Polymers (CSAS806-12), Canadian Standards Association, Mississauga, Canada, 2012.

[20] Japan Society of Civil Engineers, Recommendation for Design and Construction of Concrete Structures Using Continuous Fiber Reinforcing materials (JSCE-1997), Japan Society of Civil Engineers, Tokyo, Japan, 1997.

[21] AASHTO, Bridge Design Guide Specifications for GFRPReinforced Concrete Bridge Decks and Traffic Railings (AASHTO LRFD-17), AASHTO, Washington, DC, USA, 2017.

[22] Advisory Committee Technical Recommendations Construction, Guide for the Design and Construction of Concrete Structures Reinforced with Fiber-Reinforced Polymer Bars (CNR-DT203-06), Advisory Committee Technical Recommendations Construction, Rome, Italy, 2006.

[23] A. F. Ashour, "Flexural and shear capacities of concrete beams reinforced with GFRP bars," Construction and Building Materials, vol. 20, no. 10, pp. 1005-1015, 2006.

[24] JR Yost and S. P. Gross, "Effective moment of inertia for glass Fiber-Reinforced Polymer-Reinforced concrete beams," ACI Structural Journal, vol. 100, no. 6, pp. 732-739, 2003.

[25] S. P. Gross, J. R. Yost, D.W. Dinehart, E. Svensen, and N. Liu, "Shear strength of normal and high strength concrete beams reinforced with GFRP bars," in Proceedings of the International Conference on High Performance Materials in BridgesKona, HI, USA, 2001.

[26] A. K. El-Sayed and E. F. El-Salakawy, "Shear strength of FRPreinforced concrete beams without transverse reinforcement," ACI Structural Journal, vol. 103, no. 2, pp. 235-243, 2006.

[27] A. K. El-Sayed and E. F. El-Salakawy, "Shear capacity of highstrength concrete beams reinforced with FRP bars," ACI Structural Journal, vol. 103, no. 3, pp. 383-389, 2006.

[28] A. El-Sayed, E. El-Salakawy, and B. Benmokrane, "Shear strength of one-way concrete slabs reinforced with FiberReinforced polymer composite bars," Journal of Composites for Construction, vol. 9, no. 2, pp. 147-157, 2005.

[29] M. Benmokrane and J. P. Newhook, "Shear testing of frp reinforced concrete without transverse reinforcement," in Proceedings of the Annual Conference of the Canadian Society for Civil Engineering, Moncton, Canada, 2003.

[30] A. K. Tureyen and R. J. Frosch, "Shear tests of FRP-reinforced concrete beams without stirrups," ACI Structural Journal, vol. 99, no. 4, pp. 427-434, 2002.

[31] T. A. M. W. Nanni, "Shear strength of GFRP RC beams and slabs," in Proceedings of the 4th International Symposium, Fiber Reinforced Polymer Reinforcement for Reinforced Concrete Structures, Porto, Portugal, 2001.

[32] D. H. Deitz and I. E. Harik, "One-way slabs reinforced with glass fiber reinforced polymer reinforcing bars," in Proceedings of the 4th International Symposium, Fiber Reinforced Polymer Reinforcement for Reinforced Concrete Structures, Porto, Portugal., 1999.

[33] Y. S. Mizukawa, "A study on shear fatigue behavior of concrete beams with FRP rods," in Proceedings of the Third International Symposium on Non-metallic (FRP) Reinforcement for Concrete structures (FRPRCS-3), Sapporo, Japan, 1997.

[34] N. Duranovic, "Tests on concrete beams reinforced with glass fiber reinforced plastic bars," in Proceedings of the Third International Symposium on Non-metallic (FRP) Reinforcement for Concrete structures (FRPRCS-3), Sapporo, Japan, 1997.
[35] N. A. M. Swamy, "Structural implications of using GFRP bars as concrete reinforcement," in Proceedings of the Third International Symposium on Non-metallic (FRP) Reinforcement for Concrete structures (FRPRCS-3), Sapporo, Japan, 1997.

[36] H. Suzuki, W. Zhao, and K. Maruyama, "Shear behavior of concrete beams reinforced by FRP rods as longitudinal and shear reinforcement," in Proceedings of the Second International Rilem Symposium on Non-metallic (FRP) Reinforcement for Concrete Structures (FRPRCS-2), Ghent, Belgium, 1995.

[37] H. Nakamura and T. Higai, "Evaluation of shear strength of concrete beams reinforced with FRP," in Proceedings of the Japan Society of Civil Engineers, pp. 111-123, Tokyo, Japan, 1995.

[38] Z. P. Bažant and Q. Yu, "Safe shear design of large, wide beams," Concrete International, vol. 26, no. 8, pp. 14-17, 2004.

[39] H. Wakui and S. Tottori, "Shear capacity of RC and PC beams using FRP reinforcement," ACI Special Publication, vol. 138, no. 27, pp. 615-632, 1993.

[40] T. Nagasaka and H. Fukuyama, "Shear performance of concrete beams reinforced with FRP stirrups," ACI Special Publication, vol. 138, pp. 789-811, 1993.

[41] M. A. M. U. Issa, T. Ovitigala, and T. Ibrahim, "Shear behavior of basalt fiber reinforced concrete beams with and without basalt FRP stirrups," Journal of Composites for Construction, vol. 20, no. 4, 2016.

[42] D. Tomlinson and A. Fam, "Performance of concrete beams reinforced with basalt FRP for flexure and shear," Journal of Composites for Construction, vol. 19, no. 2, 2015.

[43] M. Guadagnini, K. Pilakoutas, and P. Waldron, "Shear resistance of FRP RC beams: experimental study," Journal of Composites for Construction, vol. 10, no. 6, pp. 464-473, 2006.

[44] C. H. Kim and H. S. Jang, "Concrete shear strength of normal and lightweight concrete beams reinforced with FRP bars," Journal of Composites for Construction, vol. 18, no. 2, pp. 1090-1268, 2014.

[45] R. S. Olivito and F. A. Zuccarello, "On the shear behaviour of concrete beams reinforced by carbon fibre-reinforced polymer bars: an experimental investigation by means of acoustic emission technique," Strain, vol. 46, no. 5, pp. 470-481, 2010.

[46] F. Matta, A. K. El-Sayed, A. Nanni, and B. Benmokrane, "Size effect on concrete shear strength in beams reinforced with Fiber-Reinforced polymer bars," ACI Structural Journal, vol. 110, no. 4, pp. 617-628, 2013.

[47] F. M. Wegian and H. A. Abdalla, "Shear capacity of concrete beams reinforced with fiber reinforced polymers," Composite Structures, vol. 71, no. 1, pp. 130-138, 2005.

[48] Z. Xiaoliang and Q. Wenjun, "Shear behavior test of GFRPreinforced concrete beams without stirrups," China Journal of Highway and Transport, vol. 23, no. 5, pp. 51-57, 2010.

[49] K. Chang and D. Seo, "Behavior of One-Way concrete slabs reinforced with GFRP bars," Journal of Asian Architecture and Building Engineering, vol. 11, no. 2, pp. 351-358, 2012.

[50] B. Abdul-Salam, A. S. Farghaly, and B. Benmokrane, "Mechanisms of shear resistance of one-way concrete slabs reinforced with FRP bars," Construction and Building Materials, vol. 127, pp. 959-970, 2016.

[51] A. S. Farghaly and B. Benmokrane, "Shear behavior of FRPReinforced concrete deep beams without web reinforcement," Journal of Composites for Construction, vol. 17, no. 6, Article ID 04013015, 2013.

[52] Z. GUO, Principles of Reinforced Concrete, Tsinghua University Press, Peiking, China, 2014. 
[53] G. Toniolo and M. di Prisco, Erratum to: Reinforced Concrete Design to Eurocode 2, Springer Tracts in Civil Engineering, Milan, Italy, 2017.

[54] ACI Commiting 318, Building Code Requirements for Structural Concrete and Commentary (ACI318-14), ACI Commiting, Farmington Hills, MI, USA, 2014.

[55] G. B. Jumaa and A. R. Yousif, "Size effect in shear failure of high strength concrete beams without stirrup reinforced with basalt FRP bars," KSCE Journal of Civil Engineering, vol. 23, no. 4, pp. 1636-1650, 2019.

[56] T. Ovitigala, Structural Behavior of Concrete Beams Reinforced with Basalt Fiber Reinforced Polymer (BFRP) Bars, University of Illinois at Chicago, Chicago, IL, USA, 2012. 